\title{
Estrogen Is Essential for Maintaining Nigrostriatal Dopamine Neurons in Primates: Implications for Parkinson's Disease and Memory
}

\author{
Csaba Leranth, ${ }^{1,5}$ Robert H. Roth,, ${ }^{2,3}$ John D. Elswoth,, ${ }^{2,3}$ Frederick Naftolin, ${ }^{1}$ Tamas L. Horvath, ${ }^{1,5}$ and \\ D. Eugene Redmond Jr2,4 \\ Departments of ${ }^{1}$ Obstetrics and Gynecology, ${ }^{2} P$ sychiatry, ${ }^{3}$ Pharmacology, and ${ }^{4}$ Neurosurgery and ${ }^{5}$ Section of \\ Neurobiology, Yale University, School of Medicine, New Haven, Connecticut 06520-8063
}

\begin{abstract}
There are sexual differences in several parameters of the nigrostriatal dopamine neurons, as well as in the progression of diseases associated with this system, e.g., Parkinson's disease and dementia. These differences, as well as direct experimental data in rodents, suggest that gonadal hormones play a role in modulating this system. To determine whether circulating estrogen might have long-term effects by altering the number of dopamine neurons, the density of dopamine neurons was calculated in the compact zone of the substantia nigra of male and intact female short- (10 d) and longer-term (30 d) ovariectomized and short- and longer-term ovariectomized but estrogenreplaced nonhuman primates (African green monkeys). Furthermore, the number of tyrosine hydroxylase-expressing neurons, the total number of all types of neurons, and the volume of the compact zone of the substantia nigra were calculated in $30 \mathrm{~d}$ ovariectomized and in $30 \mathrm{~d}$ ovariectomized and estrogen-
\end{abstract}

Gender differences are apparent in the onset and progression of Parkinson's disease (PD). Estrogen administration lowers the severity of symptoms of PD in postmenopausal women with early onset of the disease and beneficially affects certain types of memory impairments (Mayeux et al., 1992; Sherwin, 1997; Saunders-Pullman et al., 1999). The primary motor symptoms of PD and 1-methyl-4phenyl-1,2,3,6-tetrahydropyridine (MPTP)-induced parkinsonism (Ehringer and Hornykiewicz, 1960) as well as PD-related dementia and other forms of memory impairments (Ehringer and Hornykiewicz, 1960; Goldman-Rakic, 1998) in nonhuman primates are associated with the loss of mesencephalic dopamine (DA) neurons. DA cell loss during normal aging (Anglade et al., 1997) and in PD is associated, at least partly, with apoptotic cell death (Burke and Kholodilov, 1998). Any strategy shown to be effective in slowing or preventing DA cell loss should have an important impact on these DA-related disorders. Laboratory observations suggest that estrogen dramatically affects mesencephalic DA cells. A number of gender differences in DA function in the striatum and nucleus accumbens have been described in rodents (Becker, 1999). In female rats estrogen and progesterone modulate DA activity, but in male rats estrogen has no effect on striatal DA release. The DA content of striatal tissue in this species is also higher in females than in males (McDermott et al., 1994). Both tyrosine hydroxylase

Received March 16, 2000; revised Aug. 17, 2000; accepted Sept.12, 2000.

This study was supported by National Institutes of Health Grants NS 36111, HD 23830, and NS 24032. D.E.R. was supported by the Research Scientist Award MH 00643. We thank the staff at the St. Kitts Biomedical Research Foundation for their assistance with this study, especially O'Neal Whattley, Wellington Sutton, Sean O'Loughlin, Ernell Nisbett, Franklyn Conner, Ricaldo Pike, and Kristin Atterbury. We thank Dr. Michael Schwartz for helping in the statistical analyses and Marya Shanabrough for excellent technical assistance.

Correspondence should be addressed to Dr. Csaba Leranth, Department of $\mathrm{Ob}$ stetrics and Gynecology, Yale University, School of Medicine, 333 Cedar Street, FMB 328, New Haven, CT 06520-8063. E-mail: csaba.leranth@yale.edu.

Copyright (C) 2000 Society for Neuroscience $0270-6474 / 00 / 208604-06 \$ 15.00 / 0$ replaced monkeys. Unbiased stereological analyses demonstrated that a $30 \mathrm{~d}$ estrogen deprivation results in an apparently permanent loss of $>30 \%$ of the total number of substantia nigra dopamine cells. Furthermore, the density calculations showed that brief estrogen replacement restores the density of tyrosine hydroxylase-immunoreactive cells after a $10 \mathrm{~d}$, but not after a $30 \mathrm{~d}$, ovariectomy. Moreover, the density of dopamine cells is higher in females than in males. These observations show the essential role of estrogen in maintaining the integrity of the nigral dopamine system, suggest a new treatment strategy for patients with Parkinson's disease and with certain forms of memoryimpairing disorders, and provide another rationale for estrogen replacement therapy for postmenopausal women.

Key words: substantia nigra; African green monkey; ovariectomy; estrogen replacement; apoptosis; Parkinson's disease
$(\mathrm{TH})$ and DA turnover rates are higher during diestrus (rising estrogen level) than in estrus (low estrogen level) (Fernandez-Ruiz et al., 1991). Furthermore, estrogen has a protective effect against MPTP-induced neurotoxicity, including apoptosis, in mice (Dluzen et al., 1998). These data clearly indicate that estrogen has an impact on the rodent mesencephalic DA system. Most important, the finding that ovariectomy (OVX) results in a profound reduction in the density and an alteration in the morphology and distribution pattern of TH-immunoreactive axons in the prefrontal cortex of monkeys (Kritzer and Kohama, 1998) suggests that not only the integrity of axons but also the parent neurons may be dependent on circulating ovarian hormones. Because this information is relevant to human DA-dependent disorders, the effect of estrogens on DA cell survival was addressed in nonhuman primates. It is important to study primates because of the similarity of menstrual cycles and the anatomical connections and functions of the mesencephalic DA systems (Lewis and Sesack, 1997) in humans and other primates.

\section{MATERIALS AND METHODS}

Young and adult female $(n=18)$ and male $(n=3)$ African green monkeys (Cercopithecus aethiops sabaeus; of reproductive age without stigmata of advanced age) were used. The animals were housed in individual cages (water and monkey chow were provided in excess of nutritional needs) at the St. Kitts Biomedical Research Foundation (St. Kitts, West Indies). The facility is in full compliance with all applicable United States regulations, and treatment and care of these monkeys were in compliance with the Guide for the Care and Use of Laboratory Animals (1996, United States Public Health Service, Washington, DC: National Academy).

Female monkeys were divided into six experimental groups (three animals in each group): (1) intact females, (2) females that were OVX for $10 \mathrm{~d}$ (short-term) before killing, (3) short-term OVX plus $2 \mathrm{~d}$ estrogen treatment, (4) $30 \mathrm{~d}$ OVX plus $2 \mathrm{~d}$ estrogen treatment, (5) $30 \mathrm{~d}$ OVX, and (6) OVX with estrogen replacement for $30 \mathrm{~d}$. The short-term (2 d) estrogen-treated monkeys received a single injection of $150 \mu \mathrm{g}$ of estradiol benzoate in $1 \mathrm{ml}$ of sesame oil. This dose of estradiol is known to elicit a luteinizing-hormone surge (Karsch et al., 1973). The $30 \mathrm{~d}$ OVX plus 

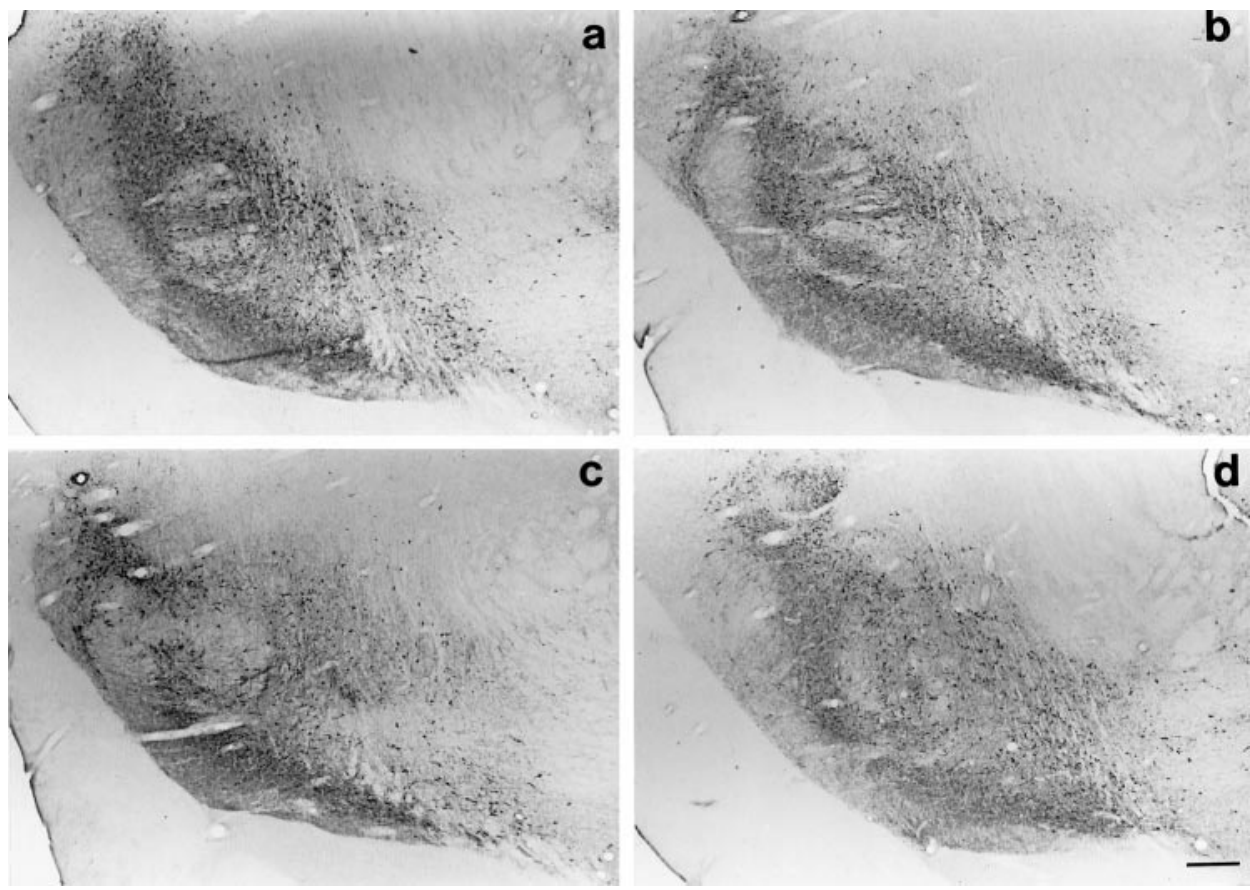

Figure 1. Light micrographs show $\mathrm{TH}-$ immunoreactive neurons in the substantia nigra of female and male monkeys. $a$, Intact female. $b$, Ten day OVX plus $2 \mathrm{~d}$ estrogentreated female. $c$, Ten day OVX female. $d$, Male. Note the higher density of THimmunopositive neurons in the intact female, male, and estrogen-treated OVX animals compared with the OVX monkey. Scale bar, $500 \mu \mathrm{m}$. estrogen-replaced animals received two $4 \mathrm{~cm}$ estrogen-filled (100\% estradiol benzoate) SILASTIC capsules that were implanted below the skin of the back, at the time of OVX. The 10 and $30 \mathrm{~d}$ OVX animals did not receive vehicles (sesame oil or empty SILASTIC capsules, respectively). According to our previous observations and those of others, these treatments do not effect gonadal hormone levels in OVX monkeys (Levine et al., 1985a,b; Leranth et al., 1992), but they require anesthesia and cause probable transient nonspecific effects, such as pain and discomfort associated with the procedures. Before killing the animals (by an overdose of pentobarbital), blood was collected from the female monkeys, and the serum estrogen level was measured by the use of radioimmunoassay (the sensitivity of the radioimmunoassay used is $>15 \mathrm{pg} / \mathrm{ml}$ ). After rinsing the vascular system with 11 of $0.9 \% \mathrm{NaCl}$ (with heparin, $1 \mathrm{U} / \mathrm{ml}$ ), animals were transcardially perfused with $1500 \mathrm{ml}$ of fixative containing $4 \%$ paraformaldehyde and $0.08 \%$ glutaraldehyde in phosphate buffer, $\mathrm{pH} 7.35$. Brains were removed, and vibratome sections cut in a frontal direction from the anteroposterior middle area of the substantia nigra pars compacta $(\mathrm{SNpc}$ 7-9 $\mathrm{mm}$ anterior from the interauricular line) were immunostained for $\mathrm{TH}$ (all samples were run in a single batch) (Leranth et al., 1998). Fiftymicrometer-thick vibratome sections were cut from the substantia nigra of animals of experimental groups $1-5$, and a $1075 \times 800 \mu \mathrm{m}$ unit area (UA $=$ $0.86 \mathrm{~mm}^{2}$ ) located lateral $(3.22 \mathrm{~mm})$ from the midline and $7 \mathrm{~mm}$ above the interauricular line was video photographed on each. The photographed field was in the center of a $3 \times 1.8 \mathrm{~mm}$ area of the $\mathrm{SNpc}$, in which the cell density is homogeneous. On the photographs (enlarged to $8.5 \times 11$ inches), only those $\mathrm{TH}$-immunoreactive neurons that contained at least a portion of the nucleus (immunonegative) were counted. Sixteen to 18 sections were counted for each monkey, with the first section selected randomly and then every 10th section thereafter (pseudorandom sample). A two-factor ANOVA test with repeated measures was used to analyze the significance of differences between groups. Post hoc analysis was performed by the Newman-Keuls test (SAS Institute, Cary, NC). Furthermore, comparative light microscopic analysis was performed on sections of the SNpc that were lightly immunostained for $\mathrm{TH}$ and counterstained with cresyl violet from intact, $10 \mathrm{~d}$ OVX, $10 \mathrm{~d}$ OVX plus estrogen-treated, and $30 \mathrm{~d}$ OVX plus estrogen-treated females and males. Only the surface area of each vibratome section that contained the immunostained neurons was analyzed because of the possible variable penetration of $\mathrm{TH}$ antibody into the sections. Because this distance cannot be quantified precisely, the resulting densities are only valid comparatively across the groups in this study. For the purpose of presenting the cell counts as density per unit volume, the volume was calculated from the $50-\mu$ m-thick section.

To confirm the comparative effects identified in the pars compacta, unbiased stereological estimates of the density of all types of neurons (stained with toluidine blue) and that of TH-immunoreactive cells were performed using the optical disector method (Gundersen et al., 1988) in monkeys in experimental groups 5 and 6 . These density counts were then corrected for the total volume of the SNpc, calculated by the method of Cavalieri (1966), to obtain values for the total number of all neurons and $\mathrm{TH}$-immunoreactive cells within the SNpc. To perform this analysis, 40 $\mu \mathrm{m}$ serial vibratome sections were cut throughout the compact zone of the $\mathrm{SN}$, and every 10th section was stained with toluidine blue, whereas the remaining sections were immunostained for $\mathrm{TH}$. After staining, dehydrating, and coverslipping the sections with Permount, the final section thick- ness was measured with a $z$-axis micrometer, and the boundaries of the SNpc were drawn for each section using a drawing tube. Thereafter, a point-counting grid was superimposed over the drawing of each section, and the volume of the SNpc $(V)$ was calculated according to the formula: $V=\Sigma P \times a(P) \times t$, where $a(P)$ is the area between grid points (corrected for magnification), $P$ is the number of grid points lying within the boundaries of the SNpc, and $t$ is the thickness of the SNpc (average section thickness $\times$ number of sections). The total number of SNpc neurons and that of TH-immunoreactive cells were determined using the optical disector method by counting stained cells in all sections of the series within a $5 \times 30 \times 30 \mu \mathrm{m}$ sampling box. The position of counting boxes was selected within each section in a systematic-random manner. Counts obtained from the sampling boxes were then extrapolated to the entire volume of the SNpc to yield the total cell number. The central feature of these techniques is the use of a systematic-random sampling that meets the statistical requirements necessary to insure an unbiased estimate of the feature of interest. After appropriate preliminary tests of distribution and variance, $t$ tests were used to determine differences between these two groups.

\section{RESULTS}

The density of TH-immunoreactive DA-producing neurons located in identical areas of the compact zone of the substantia nigra of young adult male, intact female, short- $(10 \mathrm{~d})$ and longer-term (1 month) OVX female, and short- and longer-term OVX plus estrogen-treated animals were compared (Fig. 1). The level of circulating estrogen in both 10 and $30 \mathrm{~d}$ OVX monkeys was $<15$ $\mathrm{pg} / \mathrm{ml}$. After a $2 \mathrm{~d}$ estrogen treatment of 10 and $30 \mathrm{~d}$ OVX animals, the estrogen levels increased to $420-490 \mathrm{pg} / \mathrm{ml}$. Statistical analyses (Table 1) demonstrated that (1) the DA cell density in the SNpc of intact females, males, and short-term OVX females that received estrogen $2 \mathrm{~d}$ before killing was significantly higher than that of OVX-only animals, (2) no significant difference was observed between the decrease of SNpc DA cell density of 10 and 30 d OVX females, (3) intact female monkeys had a higher SNpc DA cell density than did males, and (4) estrogen replacement for $30 \mathrm{~d}$ appears to prevent the loss of DA neurons (Table 2). Comparative light microscopic analyses demonstrated that in the $10 \mathrm{~d}$ OVX animals, a population of the $\mathrm{TH}$-immunoreactive neurons had no immunostained dendrites (Fig. $2 b$ ), although all of the TH-positive cells exhibited long, immunostained dendrites in intact females (Fig. 2a) and males and 10 and 30 d OVX plus estrogen-treated females.

To determine whether possible differences in cell size or SNpc volume might be responsible for these changes described above, we performed unbiased stereological calculations regarding the total volume of the compact zone of the $\mathrm{SNpc}$, the total number of 
Table 1. Comparative cell density analysis of the pars compacta across groups of ovariectomized females and untreated normal males and females of similar ages: serial section densities with SDs

\begin{tabular}{|c|c|c|c|c|c|}
\hline Monkey number & $\begin{array}{l}\text { Density of } \\
\text { TH/unit } \\
\text { volume }\end{array}$ & $\mathrm{SD}$ & $\begin{array}{l}\text { Number of } \\
\text { sections }\end{array}$ & $\begin{array}{l}\text { New- } \\
\text { man- } \\
\text { Keuls* }\end{array}$ & $\begin{array}{l}\% \text { intact } \\
\text { females }\end{array}$ \\
\hline \multicolumn{6}{|l|}{ Intact female } \\
\hline 1 & 2175 & 111 & 17 & & \\
\hline 2 & 2168 & 197 & 17 & & \\
\hline 3 & 2179 & 140 & 17 & & \\
\hline Mean & 2174 & 150 & & $\mathrm{~B}$ & $100 \%$ \\
\hline \multicolumn{6}{|l|}{ Male } \\
\hline 4 & 1754 & 103 & 16 & & \\
\hline 5 & 1767 & 114 & 16 & & \\
\hline 6 & 1727 & 155 & 16 & & \\
\hline Mean & 1750 & 124 & & $\mathrm{C}$ & $80 \%$ \\
\hline \multicolumn{6}{|l|}{$10 \mathrm{~d} \mathrm{OVX}$} \\
\hline 7 & 1362 & 251 & 17 & & \\
\hline 8 & 1352 & 230 & 17 & & \\
\hline 9 & 1428 & 206 & 17 & & \\
\hline Mean & 1381 & 228 & & $\mathrm{D}$ & $64 \%$ \\
\hline \multicolumn{6}{|c|}{$\begin{array}{l}10 \mathrm{~d} \text { OVX plus } 2 \mathrm{~d} \\
\text { estrogen treatment }\end{array}$} \\
\hline 10 & 2494 & 228 & 17 & & \\
\hline 11 & 2429 & 207 & 15 & & \\
\hline 12 & 2440 & 168 & 16 & & \\
\hline Mean & 2456 & 201 & & A & $113 \%$ \\
\hline \multicolumn{6}{|c|}{$\begin{array}{l}30 \mathrm{~d} \text { OVX plus } 2 \mathrm{~d} \\
\text { estrogen treatment }\end{array}$} \\
\hline 13 & 1292 & 188 & 18 & & \\
\hline 14 & 1369 & 120 & 17 & & \\
\hline 15 & 1375 & 130 & 17 & & \\
\hline Mean & 1344 & 152 & & $\mathrm{D}$ & $62 \%$ \\
\hline
\end{tabular}

ANOVA, (group) $F=482 ; \mathrm{df}=4,10 ; p<0.0001 ;$ (section) $F=0.45 ; \mathrm{df}=17,155 ; p=\mathrm{NS}$; (monkey) $F=0.59 ; \mathrm{df}=10,155$; $p=$ NS.

*Groups with same letter are not different $(p<0.05)$.

The density of TH neurons is shown.

ANOVA of TH density showed highly significant differences between the groups but no differences between the sections $(F=0.45 ; \mathrm{df}=17,155)$ or monkeys within groups $(F=0.59 ; \mathrm{df}=10,155)$ and no significant interactions in a two-factor, repeated measures design. Post hoc tests (Student; Newman-Keuls) showed that all groups were different from each other, except for the $30 \mathrm{~d}$ OVX plus $2 \mathrm{~d}$ estrogen treatment and the $10 \mathrm{~d}$ OVX without estrogen groups. Groups with the same letter are not different $(p<0.05)$.

neurons in this area, and the number of TH-immunoreactive cells. These studies were performed on six 30 d OVX monkeys; half of them received estrogen replacement immediately after OVX, which resulted in a consistent $80-90 \mathrm{pg} / \mathrm{ml}$ serum estrogen level during the period. This analysis showed that there was a small, but significant, change in the volume of the SNpc between the two groups (Table 2). Furthermore, the volume changes were in the wrong direction for them to account for the much larger differences in cell density in the pars compacta studied in the other experimental groups (Table 1). The total number of cells counted was significantly reduced without estrogen replacement, but there was no significant difference in the non-TH cells, suggesting that $\mathrm{TH}$ cells were lost instead of just failing to express their TH phenotype.

\section{DISCUSSION}

These observations show that estrogen plays a role in maintaining SNpc DA cells in primates and exerts a very rapid restorative action after short-term estrogen deprivation. At $10 \mathrm{~d}$ after OVX, at which time endogenous estrogen is practically eliminated, DA cell density decreased significantly compared with that of intact females. In addition, the data indicated that although short-term estrogen depletion dramatically reduced the density of $\mathrm{TH}$ immunoreactive SNpc cells and dendrites (or only reduced $\mathrm{TH}$ below its detection level; Fig. 2), this effect was completely reversed by estrogen restoration. Two days after estrogen replacement in these animals, the density of TH-immunoreactive neurons recovered and was even higher than that in intact females. In contrast, the effect of a more prolonged lack of estrogen $(30 \mathrm{~d})$ cannot be reversed with short-term estrogen treatment. Estrogen replacement for $2 \mathrm{~d}$ in $30 \mathrm{~d}$ OVX monkeys did not have an effect, and the density of DA neurons was no different from that seen $10 \mathrm{~d}$ after OVX alone. Furthermore, in the SNpc of these animals, all of the melanosome-containing cells located in the surface area of the sections were $\mathrm{TH}$ immunopositive, and putative (melanosomecontaining but TH-immunonegative) DA cells were not present.

It should be noted that the plasma levels of estrogen in the OVX monkeys remained $<15 \mathrm{pg} / \mathrm{ml}$ (which is the detection level of our assay system), whereas during the low estrogen days of the menstrual cycle, they are maintained at or $>80 \mathrm{pg} / \mathrm{ml}$ (Hess et al., 1979). Primate DA systems appear in general to be insensitive to native states of hormone flux (Kritzer and Kohama, 1998). In our experiments it is most likely that the severe and sustained reduction in estrogen levels is responsible for the loss of TH immunoreactivity. Therefore, such changes would probably not be normally associated with the menstrual cycle but perhaps be more likely relevant to postmenopausal phenomena.

It appears that only a certain population of DA neurons $(\sim 40 \%)$ is sensitive to estrogen deprivation up to $30 \mathrm{~d}$, because the density 


\begin{tabular}{|c|c|c|c|c|c|}
\hline Monkey number & $\begin{array}{l}\text { Density } \\
\text { of TH }\end{array}$ & Volume & $\begin{array}{l}\text { TH cell } \\
\text { count }\end{array}$ & $\begin{array}{l}\text { Non-TH } \\
\text { count }\end{array}$ & $\begin{array}{l}\text { All } \\
\text { neurons }\end{array}$ \\
\hline \multicolumn{6}{|c|}{$\begin{array}{l}30 \text { d OVX without } \\
\text { estrogen }\end{array}$} \\
\hline 16 & 1778 & 25.2 & 44,795 & 38,549 & 83,345 \\
\hline 17 & 1820 & 26.0 & 47,381 & 37,228 & 84,609 \\
\hline 18 & 1778 & 24.3 & 43,160 & 33,788 & 76,948 \\
\hline Mean & 1791 & 25.2 & 45,112 & 36,522 & 81,634 \\
\hline SD & 25 & 0.9 & 2,128 & 2,458 & 4,107 \\
\hline \multicolumn{6}{|c|}{$\begin{array}{r}30 \mathrm{~d} \text { OVX with } 30 \mathrm{~d} \\
\text { estrogen treatment }\end{array}$} \\
\hline 19 & 2211 & 30.4 & 67,114 & 43,622 & 110,736 \\
\hline 20 & 2190 & 30.8 & 67,522 & 39,210 & 106,732 \\
\hline 21 & 2218 & 31.7 & 70,351 & 38,138 & 108,490 \\
\hline Mean & 2207 & 31.0 & 68,329 & 40,324 & 108,653 \\
\hline SD & 15 & 0.7 & 1,763 & 2,906 & 2,007 \\
\hline$t$ & 25 & 9 & 14.5 & 1.73 & 10.23 \\
\hline$p$ & 0.0001 & 0.0008 & 0.0001 & NS & 0.0005 \\
\hline $\mathrm{df}$ & 4 & 4 & 4 & 4 & 4 \\
\hline
\end{tabular}

The total number of all neurons, that of TH-immunoreactive cells, their density, and the volume of the compact zone of the substantia nigra unilaterally in different experimental groups are shown.

Unbiased stereological analysis of two key groups showed small but significant differences in the total volume of the pars compacta and significant differences between the groups for TH density, total TH cell count, and total number of neurons. There was no significant difference between the groups for the count of non-TH cells.

of DA cells does not decrease further between the SNpc of $10 \mathrm{~d}$ OVX and that of $30 \mathrm{~d}$ OVX plus estrogen-treated monkeys (Table 1). This view is supported by the observation that only a population of the TH neurons, which may represent the estrogen-sensitive cells, appears to lack immunopositive dendrites, whereas the other TH-immunoreactive neurons have long, heavily immunostained processes. The dendritic loss or the reduced $\mathrm{TH}$ level in these structures could be a precursor to cell death. Experimental manipulation of the gonadal hormone levels induces structural alterations in other brain areas. For example, the lack of these hormones, shortly after OVX, greatly decreases pyramidal cell spine density in the rat CA1 hippocampal subfield and can be prevented by estrogen replacement (Woolley, 1999). However, it is not known whether estrogen administration restores the density of spines after a prolonged gonadal hormone deficiency.

The higher DA cell density in males compared with OVX females also supports the view that estrogen is necessary to maintain SNpc DA cells because males also produce a low level of estrogen as a result of aromatization of circulating androgen (Naftolin et al., 1975).

Our data suggest that $30 \mathrm{~d}$ of estrogen deprivation may result in the death of some DA neurons. Supporting this idea is the fact that dopamine neurons usually contain melanosomes. If the reduction in the density of TH-positive cells was caused by cells no longer expressing $\mathrm{TH}$, one would expect to see some melanosomecontaining but $\mathrm{TH}$-immunonegative cells, but none were present. Second, the reduction in the total density of neurons was almost identical to the reduction in TH-positive neurons (although the density of non-TH neurons was not reduced). Both of these findings would support the idea that the neurons were no longer present (had died). However, it is possible that the DA neurons were still present, but some were not expressing $\mathrm{TH}$, and that estrogen deprivation had led to the death of nearly exactly the same number of other types of neurons to explain the overall reduction in density. The finding that short-term $(2 \mathrm{~d})$ estrogen treatment of $30 \mathrm{~d}$ OVX monkeys fails to induce any recovery, as it does in $10 \mathrm{~d}$ OVX subjects, may suggest that this short period or the doses of exogenous estrogen may be inadequate and that a longer or more aggressive or complex treatment, e.g., a combination of estrogen and progesterone, might be needed to reverse the DA cell loss. It has been reported that hormone replacement of monkeys with estrogen alone was less effective in reversing the OVX-induced dramatic reduction of DA innervation of the dorsal prefrontal cortex than was a treatment involving estrogen administration followed by progesterone administration (Kritzer and Kohama, 1998). Therefore, especially considering the possible consequences of any conclusions regarding DA neuron cell death on treatment strategies in humans, further studies are needed both to characterize the mechanisms responsible for these effects and to determine whether longer, more aggressive estrogen treatment periods or combined estrogen and progesterone administration will be effective in reversing the DA cell loss observed.

A number of potential mechanisms have been proposed for the neuroprotective actions of estrogen, including the prevention of apoptosis (see Green and Simpkins, 2000; Sawada and Shimohama, 2000). This experiment does not answer the question of how estrogen protects dopamine neurons. Many adverse effects on DA cells, including MPTP treatment, induce apoptosis, and estrogen has a protective effect against MPTP-induced neurotoxicity (Dluzen et al., 1998). Therefore, it seems likely that the prolonged absence of estrogen induces apoptosis in DA neurons. Whether this estrogen action on DA neurons reflects genomic or nongenomic effects is not clear. At least in human endothelial cells, the antiapoptotic effect of estrogen is mediated by estrogen receptors (Spyridopoulos et al., 1998). In rodents, only a few TH cells located in the retrorubral field contain estrogen receptor- $\alpha$ (Kritzer, 1997), and the presence of estrogen receptor- $\alpha$ a was not reported in the SN of monkeys (Blurton-Jones et al., 1999). However, a recent study on the distribution of estrogen receptor- $\beta$ in rats demonstrated the presence of this estrogen receptor subtype in a large number of unidentified cells in ventral mesencephalic dopamine cell-containing areas (Shughrue et al., 1997). It is also possible that estrogen acts on DA cells indirectly, via other estrogen-sensitive neurons. Experiments performed on cultured hippocampal cells demonstrated that estrogen receptor-containing GABAergic interneurons are involved in the synaptoplastic effect of estrogen on the nonestrogen receptor-containing CA1 area pyramidal neurons (Murphy et al., 1998). Furthermore, we have shown that estrogen receptor-containing subcortical areas also mediate estrogenic action to the aforementioned hippocampal neurons (Leranth et al., 2000). 


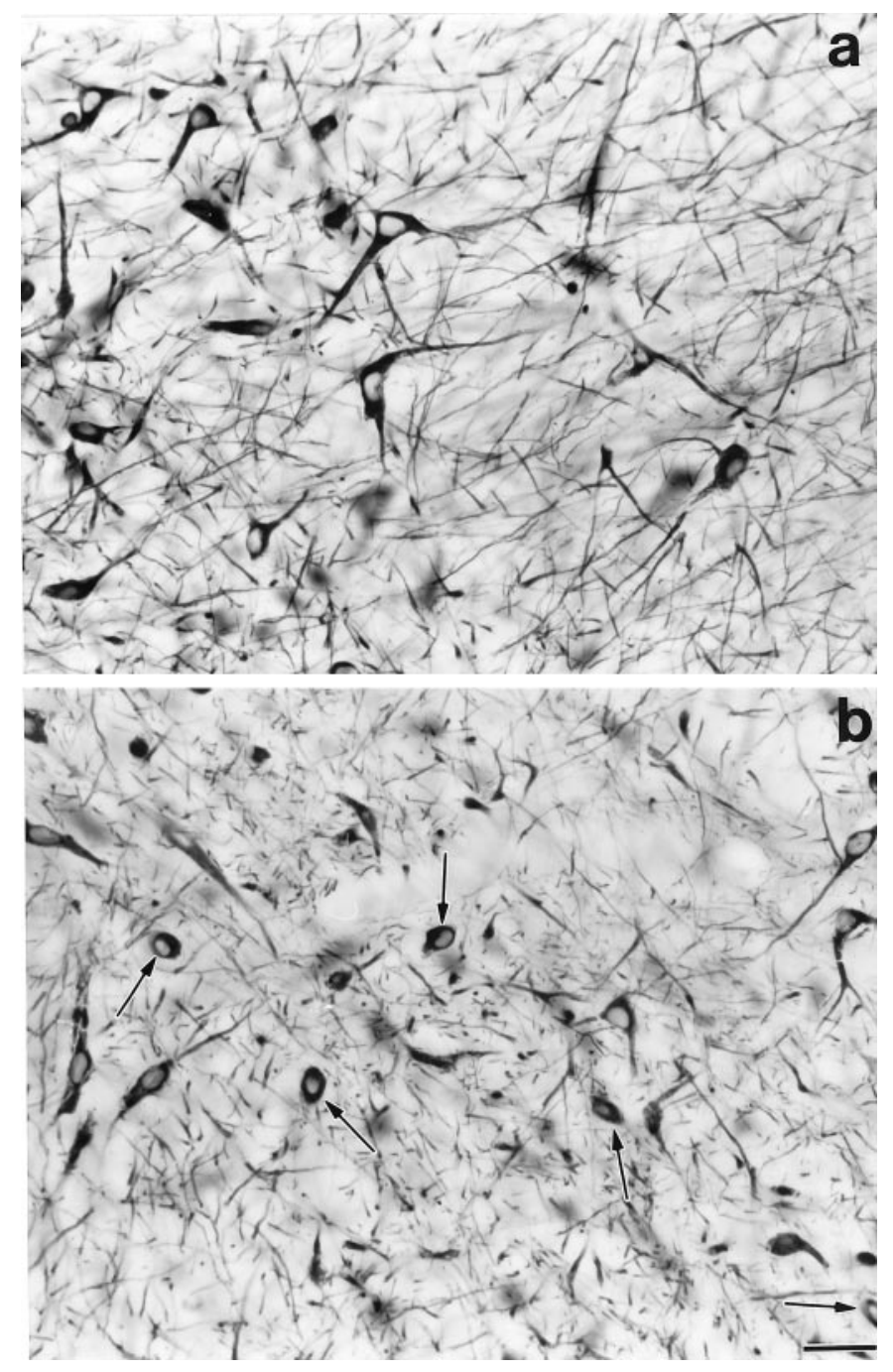

Figure 2. Light micrographs taken from the substantia nigra of an intact female and a $10 \mathrm{~d}$ OVX monkey. $a$, In the intact female, all of the THimmunoreactive neurons have long, heavily immunostained dendrites. $b$, In the OVX animal, the TH-containing cells appear to be smaller, and many of them do not exhibit immunostained dendrites (arrows). Scale bar, $20 \mu \mathrm{m}$.

Because DA cell loss during normal aging of human (Anglade et al., 1997) and nonhuman primates ( 50\%) (Emborg et al., 1998) as well as in PD (Burke and Kholodilov, 1998) is, at least partly, associated with apoptotic cell death, estrogens may play a critical role in slowing and/or preventing this process. Our findings are consistent with and help to explain epidemiological and anecdotal data, which suggest that PD progresses more slowly in women receiving hormone replacement therapy and that $\mathrm{PD}$ affects more men than women (Dluzen et al., 1998; Saunders-Pullman et al., 1999). Furthermore, controlled clinical studies, in which estrogen was administered to nondemented postmenopausal women, have found that estrogen enhances memory, as it also does in young men, and protects against memory decline (Resnick et al., 1997; Sherwin, 1997).

In addition to its role in Parkinson's disease, the mesencephalic DA system in conjunction with the prefrontal cortex has longstanding links with mnemonic and cognitive tasks (GoldmanRakic, 1998; McCarthy et al., 1996). In subhuman primates, the prefrontal cortex receives a relatively dense innervation of DA axons (Williams and Goldman-Rakic, 1993) that form specific synaptic triads (Goldman-Rakic et al., 1989). DA depletion in the prefrontal cortex induced by 6-hydroxydopamine or inf usion of DA antagonists in this cortical area produces deficits in monkeys performing working-memory tasks and disrupts performance in oculomotor-delayed response tasks, respectively (Brozosky et al., 1979; Sawaguchi and Goldman-Rakic, 1991, 1994). In contrast, administration of levodopa to parkinsonian MPTP-treated monkeys ameliorates spatial memory impairments (Fernandez-Ruiz et al., 1999). A reduced DA level in the prefrontal cortex has also been linked to cognitive disturbances of patients suffering from schizophrenia and Parkinson's disease, including substandard performance on frontal lobe tasks such as the Wisconsin Card Sorting Test (Weinberger, 1987; Goldman-Rakic, 1991). Furthermore, DA levels also dramatically decrease in the prefrontal cortex of aged monkeys (Goldman-Rakic and Brown, 1981). Therefore, protection of these vulnerable neurons by estrogen might be relevant to slowing down the progression of PD and preventing the cognitive impairment in PD and/or mnemonic and cognitive impairments associated with diseases and aging.

\section{REFERENCES}

Anglade P, Vyas S, Hirsch EC, Agid Y (1997) Apoptosis in dopaminergic neurons of human substantia nigra during normal aging. Histol Histopathol 12:603-610

Becker JB (1999) Gender differences in dopaminergic function in striatum and nucleus accumbens. Pharmacol Biochem Behav 64:803-812.

Blurton-Jones MM, Roberts JA, Tuszynski MH (1999) Estrogen receptor immunoreactivity in the adult primate brain: neuronal distribution and association with p75, trkA, and choline acetyltransferase. J Comp Neurol 405:529-542.

Brozosky TJ, Brown RM, Rosvold HE, Goldman PS (1979) Cognitive deficit caused by regional depletion of dopamine in prefrontal cortex of rhesus monkey. Science 205:929-932.

Burke RE, Kholodilov NG (1998) Programmed cell death: does it play a role in Parkinson's disease? Ann Neurol 44[Suppl 3]:126-133.

Cavalieri B (1966) Geometric degl: indivisible, pp 1-543. Torino: Unione Tipografico, Editrice.

Dluzen DE, Disshon KA, McDermott JL (1998) Estrogen as a modulator of striatal dopaminergic neurotoxicity. In: Advances in neurodegenerative disorders, Vol 1, Parkinson's disease (Marwah J, Teitelbaum H, eds), pp 149-192. Scottsdale, AZ: Prominent.

Ehringer H, Hornykiewicz O (1960) Verteilung von Noradrenalin und Dopamin (3-hydroxytriptamin) im Gehirn des Menscen und ihr Verhalten bei Erkrankungen des extrapyramidalen System. Klin Wochenschrift 38:1236-1239.

Emborg ME, Ma SY, Mufson EJ, Levei AI, Taylor MD, Brown WD, Holden JE, Kordower JH (1998) Age-related declines in nigral neuronal function correlate with motor impairments in rhesus monkeys. J Comp Neurol 401:253-265.

Fernandez-Ruiz J, Hernandez ML, de Miguel R, Ramos JA (1991) Nigrostriatal and mesolimbic dopaminergic activities were modified throughout the ovarian cycle of female rats. J Neural Transm Gen Sect $85: 223-229$.

Fernandez-Ruiz J, Doudet D, Aigner TG (1999) Spatial memory improvement by levodopa in parkinsonian MPTP-treated monkeys. Psychopharmacology (Berl) 147:104-107.

Goldman-Rakic PS (1991) Prefrontal cortical dysfunction in schizophrenia: the relevance of working memory. In: Psychopathology and the brain (Carroll BJ, Barrett JE, eds), pp 1-23. New York: Raven.

Goldman-Rakic PS (1998) The cortical dopamine system: role in memory and cognition. Adv Pharmacol 42:707-711.

Goldman-Rakic PS, Brown RM (1981) Regional changes in monoamines in cerebral cortex and subcortical structures of aging rhesus monkeys. Neuroscience 6:177-187.

Goldman-Rakic SP, Leranth C, Williams SM, Mons N, Geffard M (1989) Dopamine synaptic complex on pyramidal neurons in primate cerebral cortex. Proc Natl Acad Sci USA 86:9015-9019.

Green PS, Simpkins JW (2000) Neuroprotective effects of estrogens: potential mechanisms of action. Int J Dev Neurosci 18:347-358.

Gundersen HJ, Bagger P, Bendtsen TF, Evans SM, Korbo L, Marcussen N, Moller A, Nielsen K, Nyengaard JR, Pakkenberg B, Sorensen FB, Vesterby A, West MJ (1988) The new stereological tools: disector, fractionator, nucleator and point sampled intercepts and their use in pathological research and diagnosis. APMIS 96:857-881.

Hess DL, Hendrickx AG, Stabenfeldt (1979) Reproductive and hormonal patterns in the African green monkey (Cercopithecus aethiops). J Med Primatol 8:273-281.

Karsch FJ, Weick RF, Butler WR, Dierschke DJ, Krey LC, Weiss G, Hotchkiss J, Yamaji T, Knobil E (1973) Induced LH surges in the rhesus monkey: strength-duration characteristics of the estrogen stimulus. Endocrinology 92:1740-1747.

Kritzer MF (1997) Selective colocalization of immunoreactivity for intracellular gonadal hormone receptors and tyrosine hydroxylase in the ventral tegmental area, substantia nigra, and retrorubral fields in the rat. J Comp Neurol 379:247-260.

Kritzer MF, Kohama SG (1998) Ovarian hormones influence the morphology, distribution, and density of tyrosine hydroxylase immunoreac- 
tive axons in the dorsolateral prefrontal cortex of adult rhesus monkeys. J Comp Neurol 395:1-17.

Leranth C, MacLusky NJ, Brown TJ, Chen EC, Redmond Jr DE, Naftolin F (1992) Transmitter content and afferent connections of estrogensensitive progestin receptor-containing neurons in primate hypothalamus. Neuroendocrinology 55:667-682.

Leranth C, Sladek JR, Roth RH, Redmond ED (1998) Efferent synaptic connections of dopaminergic neurons grafted into the caudate nucleus of experimentally induced Parkinsonian monkeys are different from those of control animals. Exp Brain Res 123:323-333.

Leranth C, Shanabrough M, Horvath TL (2000) Hormonal regulation of hippocampal spine synapse density involves subcortical mediation. Neuroscience, in press.

Levine JE, Bethea CL, Spies HG (1985a) In vitro gonadotropin-releasing hormone release from hypothalamic tissues of ovariectomized estrogentreated cynomolgus macaques. Endocrinology 116:431-438.

Levine JE, Norman RL, Gliessman PM, Oyama TT, Bangsberg DR, Spies HG (1985b) In vivo gonadotropin-releasing hormone release and serum luteinizing hormone measurements in ovariectomized, estrogen-treated rhesus macaques. Endocrinology 117:711-712.

Lewis DA, Sesack SR (1997) Dopamine systems in the primate brain. In: Handbook of chemical neuroanatomy, Vol 13, The primate nervous system, Pt I (Bloom FE, Bjorklund A, Hokfelt T, eds), pp 263-375. Amsterdam: Elsevier.

Mayeux R, Denaro J, Hemenegildo N, Marder K, Tang MX, Cote LJ, Stern Y (1992) A population-based investigation of Parkinson's disease with and without dementia. Relationship to age and gender. Arch Neurol 49:492-497.

McCarthy G, Puce A, Constable RT, Krystal JH, Gore JC, Goldman-Rakic PS (1996) Activation of human prefrontal cortex during spatial and non-spatial working memory tasks measured by functional MRI. Cereb Cortex 6:600-611.

McDermott JL, Liu B, Dluzen DE (1994) Sex differences and effects of estrogen on dopamine and DOPAC release from the striatum of male and female CD-1 mice. Exp Neurol 125:306-311.

Murphy DD, Cole NB, Greenberger V, Segal M (1998) Estradiol in- creases dendritic spine density by reducing GABA neurotransmission in hippocampal neurons. J Neurosci 18:2550-2559.

Naftolin F, Ryan KJ, Davies IJ, Reddy V V, Flores F, Petro Z, Kuhn M, White RJ, Takaoka Y, Wolin L (1975) The formation of estrogens by central neuroendocrine tissues. Recent Prog Horm Res 31:295-319.

Resnick SM, Metter EJ, Zonderman AB (1997) Estrogen replacement therapy and longitudinal decline in visual memory. A possible protective effect? Neurology 49:1491-1497.

Saunders-Pullman R, Gordon-Elliot J, Parides M, Fahn S, Saunders H, Bressman S (1999) The effect of estrogen replacement on early Parkinson's disease. Neurology 52:1417-1421.

Sawada H, Shimohama S (2000) Neuroprotective effects of estradiol in mesencephalic dopamine neurons. Neurosci Biobehav Rev 24:143-147.

Sawaguchi T, Goldman-Rakic PS (1991) The role of D1-dopamine receptors in prefrontal cortex: involvement in working memory. Science 251:947-950.

Sawaguchi T, Goldman-Rakic PS (1994) The role of D1-dopamine receptors in working memory: local injections of dopamine antagonists into the prefrontal cortex of rhesus monkeys performing an oculomotor delayedresponse task. J Neurophysiol 71:515-528.

Sherwin BB (1997) Estrogen effects on cognition in menopausal women. Neurology 48[Suppl 7]:21-26.

Shughrue PJ, Lane MV, Merchenthaler I (1997) Comparative distribution of estrogen receptor-alpha and -beta mRNA in the rat central nervous system. J Comp Neurol 388:507-525.

Spyridopoulos I, Principe N, Krasinski KL, Xu Sh, Kearney M, Magner M, Isner JM, Losordo DW (1998) Restoration of E2F expression rescues vascular endothelial cells from tumor necrosis factor-alpha-induced apoptosis. Circulation 98:2883-2890.

Weinberger DR (1987) Implications of normal brain development for the pathogenesis of schizophrenia. Arch Gen Psychiatry 44:660-669.

Williams SM, Goldman-Rakic PS (1993) Characterization of the dopaminergic innervation of the primate prefrontal cortex using a dopaminespecific antibody. Cereb Cortex 3:199-222.

Woolley CS (1999) Effects of estrogen in the CNS. Curr Opin Neurobiol 9:349-354. 